\title{
Discrimination In The Workplace: Real Or Imagined?
}

Mary Easter Kunce, MPA, Drake University, USA

C. Kenneth Meyer, Drake University, USA

\begin{abstract}
This two (2) part case study presents a chronological and a narrative record of Claudia Boyle, a 48 year old woman, who has accepted an information technology position at Food for Freedom Incorporated $(F F F)$ - a Nongovernmental Organization (NGO). Full of zeal and enthusiasm, Claudia keeps up with the possibilities of career succession under Gretta Lengling, a new manager in the human resources department. By all accounts, Gretta was a "zealous achiever" and she and Claudia established a comfortable friendship at work. However, the once warm relationship quickly cooled when Claudia got sick and despite her friendship with Gretta, was passed over for a promotion when on a short-term disability leave. Faced with Gretta's justifications for hiring Derke Zykstra - a younger male - Claudia wonders if she has become a causality of both age and disability based discrimination. Advised by Gretta that she had displayed disruptive behavior, Claudia wonders if a "bad job" trumps no job at all.
\end{abstract}

Keywords: Career Succession; Age Discrimination; Disability Discrimination; Family and Medical Leave Act; Workplace Diversity; Communication; Friendship at Work; Equal Employment Opportunity Commission (EEOC)

Recommended Courses: Management, Diversity in the Workplace, Human Resources Management, Nonprofit Management, Public Personnel Administration

\section{INTRODUCTION: THE THRILL OF BEING HIRED}

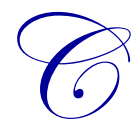

laudia Boyle had just celebrated her $48^{\text {th }}$ birthday when she accepted a full-time position as a project manager with the information technology department at Food for Freedom (FFF), Incorporated-a national, nongovernmental organization (NGO). As the newest member of the human resources technology team, Boyle is anxious to begin her new job and career in earnest and establish credibility and rapport with her team members. Throughout her career, she prided having built a solid reputation for leading successful system implementations, most recently within the American operations of a large international NGO based in the "sunbelt." She felt confident that she would quickly gain a new found recognition with her new employer, and once her credibility had been firmly established, there would be unlimited potential for advancement within FFF.

Claudia Boyle was characterized by her colleagues as having an outgoing personality that literally "bubbles with zeal and enthusiasm," and after work she enjoyed socializing with her associates. On several occasions she joined a small group of co-workers at Harry's Bar and Delicatessen - a local pub with a relaxed atmosphere where conversations often became lively and animated with plenty of speculation regarding the ongoing changes that were taking place internationally and at the national level. Having drilled into the true community connection and network, she learned from her co-workers about a new position that had been approved by the executive committee and would be announced in the near future. Claudia was eager to learn more about the position and reflect on whether her own academic and professional experiences made her a suitable fit for the job. Based on what she learned from the rumor mill, the position was a major one in FFF and would have the responsibility for leading the design and implementation of several new technology-platforms on which new initiatives in electronic human resource management (eHRM) would be based. Since this was an area that was of keen interest for Boyle, she paid close attention to what was being broadcast through the "grapevine," and, informally, she felt that her background prepared her for a higher management position and she longed for a new, exciting and challenging set of career 
opportunities. Claudia thought to herself that she would pursue the job lead with Gretta Lengling, the hiring manager, as soon as it was posted.

\section{NEW EMPLOYEES BEGIN TO BOND}

Gretta Lengling had been employed at FFF slightly less than two years. Previously, she had worked as a contract employee for several months with FFF, but was recently hired to fill a full-time management position with the human resources department. Although this was Lengling's first experience in a management role, she quickly earned the reputation for having outstanding technical skills and was soon recognized by top management as one of the "rising stars" in the organization's galaxy.

Lengling was a zealous achiever in her late thirties, and she often laughingly stated, "Beginning a slow climb on the corporate ladder." As a quick study, Gretta began developing her abilities and skills at professional networking with "relaxed ease," and while doing so had taken the essential first-steps in making herself visible to the right people within the organization. She liked to show her friends that she was not bashful to take full advantage of the after-work social gatherings and considered this environment as a chance to network and talk shop with her peers or as she put it to "... keep her ear to the ground for career enhancing chit-chat." Boyle and Lengling frequently spent time together both on and off the job. Regularly, they attended the same after work get-togethers and it was at one of these "occurrences" that Boyle learned that Lengling would be conducting interviews for the new technology program management position in human resources. As the conversation unfolded, Lengling gave Boyle her personal assurances that she would become the leading candidate once the job was formally approved and posted and the recruitment process began with earnest.

\section{WITH CLAUDIA'S ILLNESS, THE RELATIONSHIP WITH GRETTA TURNS SOUTH}

Boyle was wildly pleased that everything was going well at FFF and at the ease at which she had been accepted by her team mates. She was thankful for her current status, but, as she told Gretta, was experiencing some "minimal" health problems. She explained, in confidence, that she had experienced several instances of dizziness and shortness of breath while walking short distances, and, at times, even significant fatigue, during the last few months. Gretta listened with rapt attention to her inventory of medical complaints and showed a caring concern. The brief "spells" continued and Claudia sought professional medical advice.

Claudia underwent a series of medical tests and was diagnosed with having a serious thyroid condition, as well as a blockage in her arteries, that required open-heart surgery - "Sooner rather than later," her doctor advised. Although she had the feeling that the sands were beginning to shift beneath her feet, she was thankful that she had recently passed her one-year anniversary mark with FFF and was eligible for short-term disability benefits. She asked for and received a certification from her physician for eight weeks of short-term disability leave. Everything proceeded smoothly, and following a three hour open-heart surgical procedure, made a full recovery and was released to return to work on a full-time basis. Prophylactically, she religiously took prescription medications for her thyroid condition, but did not require any other work-related accommodations and "no restrictions" was placed on her "return to work" authorization.

During Boyle's short-term disability leave, the new technology program management position was approved for internal posting. She returned to work and resumed her previous job responsibilities, but learned that Derke Zykstra--a short-term contract worker who was hired during her leave of absence--was leading the integration project that she had initiated prior to her disability leave of absence and, to make matters even more problematic, had been identified as a top candidate for the position that Boyle sought.

Not being reticent or shy to "office politics," Boyle, in an attempt to determine the ongoing status of the recruitment and hiring process, attempted to contact Lengling on several occasions, but to no avail. Having previously experienced the recruitment and selection games that often are played in bureaucratic organizations, and knowing that she would become personally disadvantaged if she prematurely pressed the matter with Lengling, she decided that the best course of action was to "take a low-keyed, mellow approach," and follow the formal job application process. In her own mind, she was certain that if she was seen to have "jumped the chain" at this time, 
she would be viewed as being too aggressive, if not an overbearing candidate. Her precautionary approach to the application process was all in vain, however, as she was quick to learn that she was not among the top three candidates to make the final position selection list.

\section{REJECTION IS MET WITH DISAPPOINTMENT: A GRIEVANCE IS FILED}

Disappointed that she was not on the selection list, Boyle confronted Lengling about the missed opportunity for an internal promotion and asked for an explanation, to include the reasons why she was no longer on the short list of applicants that would be invited for a personal interview. To her surprise, Lengling began painting her rationale for not including Boyle on the list - reasons that Boyle dutifully remembered and that gave grist to Boyle's concerns that she had just met another "demon" of discrimination. Lengling asserted that the position required someone with physical stamina that could handle the "ebb and flow" of dealing effectively with stressful situations - a tide which Derke Zykstra as an external and experienced contract employee had ably demonstrated during the past several months. She stated, "We need somebody in the technology program management role that can handle stressful situations, and we all know what stress does to you." Although she was unsettled by these remarks, she uttered to herself that Lengling and her associates did not refer to her as being an "old geezer, "old lady," "over the hill," "too sickly," or being someone in her "golden years of a mediocre career" - at least not to her face.

Faced with the bad news of being rejected, Boyle pondered how she should deal with the concern that she might have become unwittingly a victim of disability and age discrimination. Eagerly, she researched the corporate policies regarding workplace discrimination and learned that the Employee Handbook was silent on the matter. Her desire to locate the instructions and guidelines for filing a formal grievance or requesting an internal investigation of the incident was further thwarted by the lack of procedural guidelines in the organization's handbook. Lacking a formal avenue for filing her complaint with FFF, Boyle decided to report her concern directly to the manager of the Human Resources Employee Relations Department. In her own mind, she had a good track record since joining FFF and had been instrumental in deploying several new systems that supported the goals and initiatives of the department of human resources. She believed that this innovative record of success would bolster her position and be a positive factor in her conversation with the employee relations manager. In an attempt to prepare herself should she decide to file a grievance or seek a legal remedy, she consulted the web site for the U.S. Equal Employment Opportunity Commission, and did a review of the Americans with Disabilities Act and the Age Discrimination in Employment Act, both which are briefly summarized in Exhibits 1 and 2.

Boyle quickly learned that her complaint was minimized, and to her complete surprise, she was caught offguard when she was advised that her complaint required no further investigation by the department. She was now faced with a gnawing problem. She had been rebuffed by the employee relations manager, and after discussing the situation with the other managers who comprised the Human Resources Advisory Team (HRAT), she had been told that no further action would be taken on her behalf. She wondered, however, should she continue to push harder and have her case officially investigated, or would this merely lead to personal retaliation?

Boyle soon realized that actions and inquiries have consequences and having been back at her desk for several months after having undergone major surgery, she was reassigned to work with different project teams without any further explanation, and her system access was removed for several key technology applications. In addition, she was no longer invited to participate in the ongoing implementation meetings - meetings she once led, and her interactions with Gretta Lengling and the HRAT had become visibly and uncomfortably more infrequent and tense. During the next few weeks, the situation further deteriorated and Boyle was told by Lengling during a performance counseling session in which she received an oral reprimand, that she "...had become disruptive with her team members and that her attitude needed to improve."

As the work environment continued to spiral downward, Boyle made the difficult decision to relinquish her project management responsibilities with the human resources integration team and proactively to avoid any future conflict with members of the human resources department. "After all," she reasoned, "a bad job is better than no job at the present time." Boyle was retained in the information technology department and advised to look for other 
employment opportunities - perhaps get “...a fresh, new beginning, rebuild her professional reputation, and reestablish her credibility as an organizational team player."

\section{QUESTIONS AND INSTRUCTIONS:}

1. The Americans with Disabilities Act (ADA, 1990) was signed into law to protect against specific forms of discrimination toward individuals with disabilities. The law made it illegal for an employer to retaliate against an individual who complains about discrimination or participates in an employment discrimination investigation. Based on the situation described in this case study, along with the general guidelines provided in Exhibit 1, please assess Claudia Boyle's situation and provide examples of the protections given under ADA that would warrant further review and consideration by Food for Freedom (FFF). Please be specific.

2. Under the Age Discrimination in Employment Act (ADEA), many cases involve employment terminations, such as wrongful discharge or involuntary retirement. Do you agree or disagree that the failure to consider Claudia Boyle as a viable candidate for the program manager position, based on the reasons stated by Gretta Lengling, have possible age discrimination implications for the organization? Please explain your rationale.

3. While most large organizations, regardless of the economic sphere in which they operate, display a rudimentary understanding of diversity and inclusiveness, many fail to move beyond a basic effort to be in legal compliance and, therefore, do not adopt a more comprehensive diversity and inclusion strategy. As a manager, what steps would you take to create a work environment that addresses the negative biases and perceptions often shown toward older workers or persons with disabilities? Please be specific.

4. Generally, based on your own work experience, have you ever found it difficult in your team or work environment to fully embrace diversity and, at the same time, encourage individual employees to work together as a cohesive team? If so, why? If not, why not? Please elaborate.

\section{PART 2: STOP BEFORE PROCEEDING TO A GENERAL DISCUSSION OF DISCRIMINATION}

The case on "Discrimination in the Workplace: Real or Imagined?" presents the situation in which Claudia Boyle believes, for one reason or another, that she may have been unwittingly the victim of age or disability discrimination in the workplace. This unit enables the class to examine what discrimination is about and what it basically entails. In its most basic form, discrimination means treating people in one group differently than people in another group based solely on certain perceived characteristics.

\section{A BRIEF HISTORY OF ADEA AND ADA}

When Congress passed the Age Discrimination in Employment Act in 1967 (ADEA), one of its primary goals was to promote the employment of older individuals based on their ability rather than on their age. In 1990, when Congress passed the Americans with Disabilities Act (ADA, 1990), it was designed to eliminate employment barriers for people with disabilities. More than two decades after ADA was enacted, a number of barriers continue to impact the ability of disabled individuals to overcome problems of stereotyping and negative perceptions about hiring people with disabilities.

While age alone is not considered to be a disability under ADA, data from the U.S. Census Bureau and other important research venues, clearly demonstrate that a positive correlation exists between disability and age. Research indicates that as the population grows older, the number of Americans that report having one or more physical or mental disabilities tends to increase.

Overall, a perplexing question remains unanswered on whether the ADA and ADEA laws may have had an "adverse impact" on those they were designed to protect, especially if organizations are reluctant to hire and promote those protected by these powerful national laws. 


\section{CONSULTANTS REPORT ON FFF'S ORGANIZATIONAL CULTURE}

In summation, a year after the workplace incident that affected Claudia Boyle, FFF hired an outside consultant to do focus group based research and give employees an opportunity to provide feedback on a number of diversity-related questions. The research revealed the following perceptions at FFF:

1. On a scale of 0 to 10 , the focus group participants gave FFF an average rating of 5.1 on diversity topics;

2. Four key priorities were identified by focus group participants, including a need to review hiring and promotion procedures and other human resource management practices;

3. Participants felt that a cultural change was needed to engage employees with diverse backgrounds and to develop an environment where employees could become more united and cohesive around the organizational mission and vision statements; and,

4. An Employee Advisory Council (EAC) was formed, under the leadership of the CEO, and it later morphed into the Council for Diversity and Inclusiveness (CDI). The council concluded that FFF should promote the employment and promotion of older workers based on their ability and not on their age.

A review of the Equal Employment Opportunity Commission (EEOC), the federal agency responsible for enforcing the Equal Employment Opportunity Act (EEOA), laws which make it unlawful to discriminate on the basis of the five factors included in the Civil Rights Act of 1964 (race, religion, national origin, sex, and color), plus age, disability and genetic information, revealed that the bulk of their claims are in the area of age, disability, sex, race and retaliation. It is the practice of EEOC to attempt to resolve discrimination charges through alternative dispute resolution measures, but if they fail, they may elect to file a civil suit within 120 days. Also, EEOC uses education and other outreach activities to inform organizations of the anti-discrimination polices and, therefore, seek voluntary compliance with EEOC regulations and affirmative action programs, rather than relying on adverse control techniques. Discriminatory practices in any phase of the employment process (advertisement, selection, hiring, promotion, training, dismissal, etc.) which serve as barriers to opportunity for a protected group are deemed unlawful.

\section{QUESTIONS AND INSTRUCTIONS:}

1. Please consult at least one Employee Handbook and identify the procedure that is to be used in filing a grievance. Do you feel that the procedure is an adequate one? Please explain. If not, how would you revise or modify it so that the rights of employees would be procedurally and substantively protected. Please elaborate.

2. If the city and state in which you reside have a human rights commission, please contact it or one which receives discriminatory complaints from its residents. Please indicate the number and percent of discrimination cases filed, by type, for the past ten year period. What trends if any are you able to identify? Please explain.

\section{AUTHOR INFORMATION}

Mary Easter Kunce is a Process Excellence Project Manager at LifeServe Blood Center in Des Moines, Iowa. Mary has a rich background of experience across a broad range of corporate disciplines, including project management, performance metrics, audits and financial reporting, human resources administration, data management and regulatory compliance. She has previously held positions with Aviva Life and Annuity Company in West Des Moines, Iowa as a Process Improvement Consultant in Insurance Operations, Wellmark Blue Cross and Blue Shield in Des Moines, Iowa as an Employee Benefits Consultant, and Pioneer Hi-Bred International where she supported Six Sigma deployment efforts through delivery of classroom training and mentoring programs. Throughout her career, Mary has been a strong advocate for Process Excellence and a facilitator and leader of process improvement initiatives. Mary earned a B.S. degree in Business Administration from Truman State University and a Master of Public Administration from Drake University.

C. Kenneth Meyer is Thomas F. Sheehan Distinguished Professor of Public Administration, Drake University. He previously held teaching positions at Winona State University, State University of New York, University of South 
Dakota and the University of Oklahoma, Norman, Oklahoma. He has nearly 300 published case studies that appear in numerous venues. His latest books are entitled: Managing People as Assets; Human Relations in Action; Managing America's Organizations; and Managing Public Service Organization; Conducting the People's Business; and Organizational Change. He has co-authored other case studies with Alison Lemke, Steven Clapham and Richard Strong, and has dozens of articles in a number of other business, public administration, and criminology journals. His newest book, with Jeffrey Geerts is entitled Nonprofit Management and Leadership Case Studies (2014). E-mail: Kenneth.Meyer@Drake.edu

\section{REFERENCES}

1. Boushey, H. \& Glynn, S. J. There Are Significant Business Costs to Replacing Employees. Center for American Progress. November 16, 2012. Retrieved on May 15, 2014 from http://www.americanprogress.org/issues/labor/report/2012/11/16/44464/there-are-significant-business-costs-toreplacing-employees/

2. Cañas, K. A., and Sondak, H. (2008). Opportunities and Challenges of Workplace Diversity: Theory, Cases, and Exercises. Upper Saddle River, NJ: Pearson/Prentice Hall

3. Carnevale, D. G. (1995). Trustworthy government: Leadership and management strategies for building trust and high performance. San Francisco, CA: Jossey-Bass Publishers.

4. Clapham, S. E., Meyer, C. K., Caldwell, C., and Proctor, G.B., Jr. (2014). Trustworthiness, Justice and the Mediating Lens, Journal of Business and Behavioral Sciences, 26, 55-74.

5. Dursi, M. (2008). Can Health Promotion Programs Effectively Reduce Health Care Costs, Increase Productivity and Retain Qualified Employees? University of Rhode Island. Retrieved from http:/www.uri.edu/research/lrc/research/papers/Dursi-Healthcare.pdf

6. $\quad$ "End of the Boom: Retiring Baby Boomers and the Consequences for Your Business." Tandem HR, 2010. Web. 29 Mar. 2014. <http://www.tandemhr.com/userfiles/file/Exit\%20of\%20Baby\%20Boomer

7. Equal Employment Opportunity Commission, "Facts about the Americans with Disabilities Act," http://www1.eeoc.gov//eeoc/publications/, accessed 6/29/2014.

8. Gabarro, L. (1978). The development of trust, influence, and expectations. In A. G. Athos and J. J. Gabarro (Eds.), Interpersonal behavior: Communication and understanding in relationship. Englewood Cliffs. NJ: Prentice Hall.

9. Guy, M. E., \& Killingsworth, J. (2007). "Framing Gender, Framing Work: The Disparate Impact of Traditional HRM Practices.” In A Farazmand (ed.), Strategic Public Personnel Administration: Building and Managing Human Capital for the $21^{\text {st }}$ Century. Westport, CT: Praeger, 399-418.

10. Jackson, E. The Top 8 Reasons Your Best People Are About To Quit - And How You Can Keep Them. Forbes. May 11, 2014. Retrieved on May 15, 2014, from http://www.forbes.com/sites/ericjackson/2014/05/11/the-top-8reasons-your-best-people-are-about-to-quit-and-how-you-can-keep-them/

11. Lewicki, R. J., McAllister, D. J., \& Bies, R. J. (1998). Trust and distrust: New relationships and realities. The Academy of Management Review, 23(3), 438-458.

12. Lubin, W. (2014). Is Gender Inequality Still an Issue in the Workforce. Retrieved from http://ivn.us/2014/03/17/gender-inequality-still-an-issue/.

13. Lucas, S. How much does it cost companies to lose employees? CBS Money Watch. November 21, 2014. Retrieved on May 15, 2014, from http://www.cbsnews.com/news/how-much-does-it-cost-companies-to-loseemployees/

14. $\quad$ Meyer, C. K., Noe, L. J., Lance J. Noe, Jeffrey A., Geerts, J. A., \& Frank, G. L. (2010). Organizational change: Technology, workplace, workforce. Des Moines, IA: Millennium HRM Press.

15. Meyer, C. K., Noe, L. J., Lance J. Noe, Jeffrey A., Geerts, J. A., \& Frank, G. L. (2012). Managing People As Assets. Des Moines, IA: Millennium HRM Press.

16. Reina, D. S., \& Reina, M. L. (1999). Trust and betrayal in the workplace. San Francisco: Berret-Koehler.

17. Sandberg, S. (2013). Lean In: Women, Work, and the Will to Lead. New York: Knopf.

18. Selden, S. C. (2009). Personnel and Human Resource Management in the States, in Hays, W. W., Kearney, R.C., \& Coggburn, J.D. Public Human Resource Management. New York: Pearson,46-63.

19. U.S. Census Bureau. (2006). Selected characteristics of baby boomers 42 to 60 years old in 2006. Retrieved from http://www.census.gov/population/age/publications/files/2006babyboomers.ppt

20. Wieczner, J. 2013. Your Company Wants to Make you Healthier. The Wall Street Journal. Retrieved from http://online.wsj.com/news/articles/SB10001424127887323393304578360252284151378 


\section{Exhibit 1: Brief Summary of Americans with Disabilities Act (ADA)}

The Americans with Disabilities Act of 1990 (ADA) makes it unlawful to discriminate against a qualified individual in all employment practices, including the following:

- $\quad$ Recruitment and job applications

- $\quad$ Hiring, firing and layoffs

- $\quad$ Training and development

- $\quad$ Promotions, advancements and job assignments

- $\quad$ Compensation, benefits and tenure

To be considered as an individual with a "disability" that qualifies for ADA protections, a person must meet one of the following conditions:

1) He / she must have a physical or mental impairment that substantially limits a major life activity.

2) $\mathrm{He} / \mathrm{she}$ must have a record of such an impairment as described below.

3) $\mathrm{He} / \mathrm{she}$ is "regarded" as having such an impairment.

The following is a brief summary of terms that are relevant to the discussion of whether a person satisfies the ADA definition of "disability.

- $\quad$ Impairment - refers to a physiological disorder affecting one or more of a number of body systems or a mental or psychological disorder.

- Major Life Activities - several examples are included in the regulations, including the following: caring for oneself, performing manual tasks, walking, seeing, hearing, speaking, breathing, learning, and working.

- Substantially Limits - whether the impairment substantially limits a major life activity depends on the nature and severity of the impairment, the duration or expected duration of the impairment, and the permanent or long-term impact of the impairment. Temporary restrictions generally are not substantially limiting, but temporary impairments that take significantly longer than normal to heal, long-term impairments, or potentially long-term impairments of indefinite duration may be disabilities if they are severe.

- $\quad$ Record - An individual has a record of a substantially limiting impairment if she or he has a history of a substantially limiting impairment, or if they have been misclassified as having a substantially limiting impairment.

- $\quad$ Regarded - An individual is regarded as having a substantially limiting impairment if he or she a) has no impairment, but is treated by an employer as though a substantially limiting impairment exists, or b) has an impairment that does not substantially limit major life activities but they are treated by an employer as though they have this kind of impairment.

Source: Exhibit prepared on information reported by the U.S. Equal Employment Opportunity Commission, Executive Summary: Compliance Manual Section 902, Definition of the Term "Disability".

\section{Exhibit 2. Brief Summary of Age Discrimination in Employment Act (ADEA)}

The federal Age Discrimination in Employment Act of 1967 (ADEA) protects employees and job applicants age 40 years of age or older from employment discrimination based on age. Age discrimination involves the treatment of an applicant or an employee less favorably based on his or her age.

It is a further violation of the ADEA to retaliate against an employee or an applicant for opposing employment practices that discriminate based on age, or for filing a complaint or participating in an investigation regarding age discrimination. 


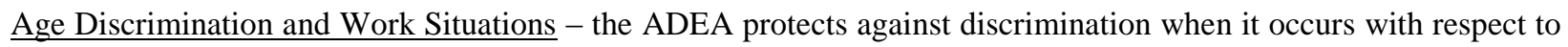
any of the following aspects of employment:

- $\quad$ Hiring, firing and layoffs

- Job notices and advertisements

- $\quad$ Pre-employment inquiries

- $\quad$ Training and development opportunities

- $\quad$ Promotions, advancements and job assignments

- $\quad$ Compensation, benefits and tenure

Age Discrimination and Employment Policies/Practices -- age discrimination can occur for many reasons, and any employment policy or practice can be illegal if it has a negative impact on applicants or employees age 40 or older. Some studies suggest that there are common reasons that employers prefer younger workers, including the following:

- $\quad$ Shorter careers by older workers mean a greater human capital investment

- $\quad$ Older workers lack energy

- $\quad$ Employer costs for health insurance, life insurance and pensions increase due to older workers

- $\quad$ Older workers are less flexible or adaptable

- $\quad$ Older workers demand higher salaries

- $\quad$ Older workers have greater health risks and more absences

- $\quad$ Knowledge and skills for older workers are obsolete

- $\quad$ Older workers block the career paths of younger workers

- Job competence for older applicants can be overstated

- Employers risk of a discrimination lawsuit is greater when they bring older workers into their organization

Source: Exhibit prepared on information reported by the U.S. Equal Employment Opportunity Commission, "Facts about Age Discrimination."

\section{Discrimination in the Workplace: Real or Imagined}

Name:

\section{Case Log and Administrative Journal Entry}

This case analysis and learning assessment may be submitted for either instructor or peer assessment

\section{Case Analysis:}

Major case concepts and theories identified:

What is the relevance of the concepts, theories, ideas and techniques presented in the case to that of public or private management? 
Facts - what do we know for sure about the case? Please list.

Who is involved in the case (people, departments, agencies, units, etc.)? Were the problems of an "intra/interagency" nature? Be specific.

Are there any rules, laws, regulations or standard operating procedures identified in the case study that might limit decision-making? If so, what are they?

Are there any clues presented in the case as to the major actor's interests, needs, motivations and personalities? If so, please list them.

\section{Learning Assessment:}

What do the administrative theories presented in this case mean to you as an administrator or manager?

How can this learning be put to use outside the classroom? Are there any problems you envision during the implementation phase?

Several possible courses of action were identified during the class discussion. Which action was considered to be most practical by the group? Which was deemed most feasible? Based on your personal experience, did the group reach a conclusion that was desirable, feasible, and practical? Please explain why or why not.

Did the group reach a decision that would solve the problem on a short-term or long-term basis? Please explain.

What could you have done to receive more learning value from this case? 


\section{NOTES}

